This journal is the official publication of Bangladesh Society of Physiologists (BSP)

Web URL: www.banglajol.info/index.php/JBSP

Abstracted /indexed in Index Copernicus, Director of Open Access Journal, HINARI Index Medicus for South East Asia Region, Google Scholar, 12OR, infobse index, Open J gate, Cite factor, Scientific indexing services

pISSN-1983-1213; e-ISSN-2219-7508

\title{
Article
}

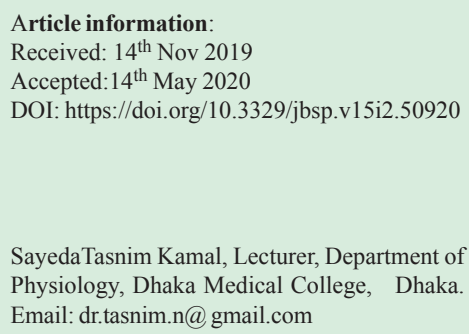

SayedaTasnim Kamal, Lecturer, Department of Physiology, Dhaka Medical College, Dhaka. Email: dr.tasnim.n@gmail.com

Cite this article:

Kamal ST, Akhter QS. Effects of exposure to textile dye on serum Alkaline Phosphatase and Gamma glutamyl transferase levels in textile industry workers.

J Bangladesh Soc Physiol 2020;15(2): 68-71

This article is open access licensed under CC BY NC SA which allows readers copy, distribute, display, and perform the work and make derivative works based on it only for noncommercial purposes.

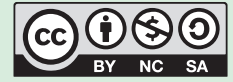

\section{Effects of exposure to textile dye on serum Alkaline Phosphatase and Gamma Glutamyl Transferase levels in textile industry workers}

\author{
SayedaTasnim Kamal ${ }^{1}$, Qazi Shamima Akhter ${ }^{1}$ \\ 1. Department of Physiology, Dhaka Medical College, Dhaka.
}

\section{Abstract}

Background: The textile dyeing industry uses large number of chemicals, acids and dyes. The workers are exposed to these chemicals during their daily work activities. Chronic exposure to these chemicals may have adverse effect on the liver functions, as liver plays an important role in detoxification of these chemicals.Objective: To assess serum Alkaline Phosphatase (ALP) and Gamma glutamyl transferase (GGT) levels of the industrials workers exposed to textile dyes. Methods: This cross sectional study was carried out in the Department of Physiology,Dhaka Medical College, Dhaka from July 2016 to June 2017 on 25 apparently healthy male workers aged 20-40 years working in a textile dye factory for 2 years or more. Similar age, sex, BMI \& socioeconomically matched 25 apparently healthy non exposed workers were enrolled as control. Serum ALP and GGT levels were estimated by autoanalyzer. For statistical analysis unpaired Student's t-test were performed Results: Serum ALP and GGT levels were significantly higher in textile dye exposed workers than those of control group ( $p$ $<0.05$ ). Conclusions: This study reveals that exposure to textile dyes have deteriorating effect on liver function.

Key words: Textile dyes, textile industry workers, liver enzymes.

Introduction

n occupational disease is any disease contracted
primarily as a result of an exposure to risk factors
arising from work activity. ${ }^{1}$ In Bangladesh, about 1727 workers died and 2307 workers were injured in different workplace accidents in the year $2013 .^{2}$ From ancient period, 
the textile and clothing industries are the growing and widest industries around the world. In Bangladesh, textile industry is the second largest industry after agriculture in terms of number of persons employed. It is the main source of employment and export for our country. ${ }^{3-4}$

For any fabric, color is the main attraction. Adding color to textile products like fibers, yarns and fabrics is called dyeing. A variety of chemicals are used by the textile processing industry for dyeing and printing. The exposure includes not only the dyes, but also different organic solvents (formaldehyde, benzene, toluene, styrene etc.), bleaching agents, acids, alkalies etc. These chemicals are toxic in nature due to their chemical structure. ${ }^{5}$

Skin contact, ingestion and inhalation are the important routes by which these chemicals can enter in to the body. Systemic adverse effects occur when they distributed throughout the body by blood. ${ }^{6-8}$ Short term exposure to these chemicals shows little or no effects to workers. However, chronic exposure to textile dyeing chemicals can lead to different type of diseases. Skin allergies (dermatitis, pruritus etc.), respiratory diseases (rhinitis, asthma, bronchitis etc.), allergic cojunctivitis, headache, depression and musculoskeletal disorders are most common. Chronic exposure may also lead to different cancers like hepatocellular, nasal, esophageal, lung, gastric, colon and rectal. 6,9

Liver is the main organ responsible for biotransformation and detoxification process of these chemicals and solvents used in textile processing industries. As a result, it becomes the prime target organ for the chemical induced tissue injury. ${ }^{7}$ On the basis of this background, the present study was designed to assess the serum ALP and serum GGT levels in textile processing and dyeing industry workers.

\section{Methods}

This cross sectional study was carried out from July 2016 to June 2017 in the Department of
Physiology, Dhaka Medical College, Dhaka to observe the effect of exposure to textile dye on serum ALP and GGT levels in 25 apparently healthy workers aged 20-40 years. They were enrolled from dyeing section of a textile industry working for 2 years or more by purposive sampling. Age, sex, BMI \& socio-economically matched 25 apparently healthy non exposed workers were enrolled as control from different section of that industry.

The protocol of this study was approved by the Research Review Committee and Ethical Review Committee of Dhaka Medical College, Dhaka. Those who have history of previous or current viral hepatitis and blood transfusion within last 3 months; regular alcohol consumption and regular smoking were excluded from the study. After briefing about the study, informed written consent was taken from each subject. Detail family, medical history and socioeconomic information were recorded in a preformed data shit and thorough physical examination was done. Anthropometric measurement including height and weight were taken and BMI were calculated. Blood pressure was also measured. Then venous blood was collected under aseptic precautions for estimation of serum ALP and GGT levels by auto analyzer.

For statistical analysis unpaired Student's t-test were performed by computer based statistical software SPSS version 22. Data were expressed as mean \pm SD. The $\mathrm{p}$ value $<0.05$ was taken as level of significance.

\section{Results}

General characteristic of all subjects are presented in Table I. Both groups were comparable in respect of age, BMI and socioeconomic condition. The mean \pm SD serum ALP level and GGT level was significantly higher ( $\mathrm{P}$ value $<0.001)$ in dye exposed worker compared to non-exposed worker. (Table II).

Volume 15 No. 2 December 2020: 68-71 
Table I: General characteristics of the subjects in both groups $(\mathrm{N}=50)$

\begin{tabular}{lcc}
\hline Parameters & \multicolumn{2}{c}{ Groups } \\
\cline { 2 - 3 } & Dye Exposed $(\mathrm{n}=25)$ & Non Exposed $(\mathrm{n}=25)$ \\
\hline Age $($ years $)$ & $26.60 \pm 6.13$ & $29.16 \pm 4.75$ \\
BMI $\left(\mathrm{kg} / \mathrm{m}^{2}\right)$ & $22.24 \pm 3.45$ & $23.51 \pm 3.09$ \\
Socioeconomic condition & & \\
Low & $25(100 \%)$ & $25(100 \%)$ \\
Systolic BP $(\mathrm{mm} \mathrm{Hg})$ & $113.60 \pm 4.90$ & $117.00 \pm 8.16$ \\
Diastolic BP $(\mathrm{mm} \mathrm{Hg})$ & $64.00 \pm 6.92$ & $67.00 \pm 8.66$ \\
\hline
\end{tabular}

Results are expressed as mean and standard deviation (mean $\pm \mathrm{SD}$ ). Unpaired Student's t-test was done to compare between the groups. $p$ value $<0.05$ was accepted as level of significance. $\mathrm{N}=$ Total number of subjects. $\mathrm{n}=$ Number of subjects in each group.

Table II: Study parameters of the subjects in both groups $(\mathrm{N}=50)$

\begin{tabular}{lcc}
\hline Laboratory parameters & \multicolumn{2}{c}{ Groups } \\
\cline { 2 - 3 } & Dye Exposed $(\mathrm{n}=25)$ & Non Exposed $(\mathrm{n}=25)$ \\
\hline Serum ALP (U/L) & $117.44 \pm 34.04^{* * *}$ & $62.44 \pm 7.93$ \\
Serum GGT (U/L) & $46.88 \pm 16.60^{* *}$ & $37.19 \pm 3.69$ \\
\hline
\end{tabular}

Results are expressed as mean and standard deviation (mean \pm SD). Unpaired Student's t-test was done to compare between the groups. $p$ value $<0.05$ was accepted as level of significance. $n=$ Number of subjects in each group, $\mathrm{ALP}=$ Alkaline phosphatase, GGT $=$ Gamma Glutamyl Transferase. ${ }^{* * *} p<0.001$.

\section{Discussion}

This study demonstrated significantly higher serum ALP among dye workers than that of non-exposed adult. Almost similar types of results were found by many researchers. ${ }^{10-12}$ On the other hand, many researchers of different country did not find any significant change of serum ALP level in between two groups. ${ }^{13-14}$ The mean serum GGT level was significantly higher in exposed dye workers than that of adult healthy non-exposed workers. This finding was in agreement with the study of many researchers of different countries. ${ }^{12-13,15}$ However no significant change in GGT was found by some authors. ${ }^{16}$

Significantly increased serum ALP and GGT level in these group of workers having olume 15 No. 2 December 2020: 68-71 occupational exposure to fabric dyeing is most likely due to hepatocellular and canalicular membrane damage. The damage is caused by injurious intermediate metabolites (epoxides, carbonium, notrenium etc.) produced during biotransformation of the dyes and associated chemicals in liver. These injurious intermediate metabolites bind with liver CYP 450 enzyme and activate them, resulting further production of the intermediate metabolites. All these intermediates bind with cellular proteins, DNA \& RNA and damage them. ${ }^{17-19}$

Again, several studies showed these injurious metabolites may cause bile canalicular membrane damage and disruption of transport protein by binding with them. These may result impaired bile 
secretion and flow so there may be cholestasis. Thus, there is accumulation of bile acids, bile salts and cholesterol in hepatocytes. These causes further damage of the membrane by reducing their fluidity and also impairs the functions of membrane proteins leading to release of hepatic sinusoidal and canalicular enzymes in blood ${ }^{20-22}$.

\section{Conclusion}

After analyzing the results of the study, it can be concluded that textile dye and associated chemicals has injurious effect on liver enzymes in the workers.

\section{Conflict of interest None}

\section{References}

1. WHO. Programmes: Occupational health [Internet]. Geneva: World Health Organization; c 2016. Occupational and work-related diseases; 2016 [cited 2016 Mar 3]. Available from: http://www.who.int/ occupational_health/activities/occupational_ work_diseases/en/

2. Dhaka: Asian Network for the Rights of Occupational and Environmental Victims; [cited 2016 Oct 16]. Available from http://www.anroev.org/2014/01/11/ anroev-1841-bangladesh-workplace-accident-surveyreport-2013/.

3. Keane J, teVelde DW. Overseas Development Institute. [Internet]. London. The role of textile and clothing industries in growth and development strategies; 2008. Available from: https://www.odi.org/publications/ 2493-role-clothing-textile-industries-growthdevelopment-strategies.

4. Hasanat DR. The future of RMG trade. The Daily Star. 2015 [cited 2016 Oct 15]; Available from: http:/ /www.thedailystar.net/ supplements/24th-anniversarythe-daily-star-part-1/the-future-rmg-trade-73288.

5. Chang WJ, Joe KT, Park HY, Jeong JD, Lee DH. The relationship of liver function tests to mixed exposure to lead and organic solvents. Ann Occup Environ Med. 2013;25(5):1-12.

6. Wernli KJ, Astrakianakis G, Camp JE. Development of a job exposure matrix (JEM) for the textile industry in shanghai, China. J Occup Environ Hyg 2006;3(10):521-29.

7. Liaqat I, Arshad M, Arshad N. Changes in selected blood biochemical components of industrial workers occupationally exposed to textile dyes: A preliminary study. Pakistan J. Zool 2009;41(1):65-9.

8. Uboh FE, Ufot S. Withdrawal from exposure reverses hematotoxicity and hepatotoxicity caused by oral exposure to nitrocellulose thinner in male rats. $\mathrm{J}$ ClinToxicol 2013;3(5):1-6.

9. Upadhyay KK, Pandey AC. Occupational exposure and awareness of occupational safety and health among cloth dyeing workers in Jaipur India. Iranian J Health, Saf Environ 2015;3(2):540-6.

10. Mohammadi S, Mehrparvar A, Labbafinejad Y, Attarchi MS. The effect of exposure to a mixture of organic solvents on liver enzymes in an auto manufacturing plant. J Public Health 2010;18(6):553-7.

11. Khan AA, Sultan R, Zamani GY, Rahman SU. Biochemical and hematological analysis after exposure to hazardous materials during shoe making. J Biology Life Sci. 2013;4(2):116-38.

12. Ibrahim KS, Amer NM, El-dossuky EA, Emara AM, El- Fattah AES, Shahy EM. Hepatic dysfunction and immune suppression among Egyptian workers occupationally exposed to benzene. Int Public Health Forum. 2014;1(4):1-6.

13. Sancini A, Caciari T, Chighine A, Gioffre PA, Andreozzi G, Sacchi L, Giubilati R, Tomei G, Suppi $\mathrm{A}$, Sacco $\mathrm{C}$ et al. Workers of the printing industry and hepatic damage. Ann Ig 2014;26:321-9.

14. Taofeeq O, Olayinka RG, Taiwo OO, Ganiyu AO, Kabiru DM, Suleiman MA. Organic solvent exposure: hepatotoxicity, nephrotoxicity, and haematotoxicity assessment amongst vehicle spray painters in Ile-Ife, Nigeria. Am J Environ Prot. 2015;3(3):95-9.

15. Hussein ASA, AbdallaMSh, Hussein JS, WafaaGh. ShoushaWGh, Mohamed AH. Antioxidants in shoemakers exposed to organic solvents. J Appl Sci Res. 2008;4(9):1107-17.

16. Padmanaban P, Deept GN, Sarkar G, Sarkar M. Biochemical parameters of paint workers in Puducherry. Chron Young Sci 2011;2(1):59-60.

17. Ioannides C. 2001. Enzyme systems that metabolise drugs and other xenobiotics. 1st ed. England: Wiley. 600 p. Chapter 1, Xenobiotic metabolism: an overview; p. 17-19.

18. Ioannides C, Lewis DF. 2004. Cytochromes P450 in the bioactivation of chemicals. Curr top Med Chem 4(16): 1767-88.

19. Cullen JM. 2005. Mechanistic classification of liver injury. Toxicol pathol 33 (1): 6-8.

20. Boelsterli UA. Mechanistic toxicology: the molecular basis of how chemicals disrupt biological targets. London: Taylor \& francis; 2003. 314 p. Chapter 6, Disruption of cellular calcium homeostasis; p. 14855.

21. Thapa BR and Walia A. Liver function tests and their interpretation. Indian J Pediatr 2007;74(7):663-71.

22. Hofmann AF.The continuing importance of bile acids in liver and intestinal disease. Arch Intern Med 1999;159(22):2647-58.

Volume 15 No. 2 December 2020: 68-71 